\title{
The Effectiveness of E-Learning in Dealing With Psychiatric Problems for Doctors and Nurses in Primary Care Facilities: A Literature Review
}

\author{
Shanti Wardaningsih ${ }^{1, *}$ Warih Andan Puspitosari ${ }^{2}$ Asroni $^{3}$ \\ ${ }^{1}$ Magister of Nursing, Universitas Muhammadiyah Yogyakarta Indonesia \\ ${ }^{2}$ Magister of Nursing, Universitas Muhammadiyah Yogyakarta Indonesia \\ ${ }^{3}$ Faculty of Engineering, Universitas Muhammadiyah Yogyakarta Indonesia \\ ${ }^{*}$ Corresponding author. Email: shanti.wardaningsih@umy.ac.id
}

\begin{abstract}
Handling of psychiatric cases in the community and at the healthcare center is a vital aspect for further treatment of people with mental health disorders. Hence, healthcare workers (doctors and nurses) are required to carry out this crucial intervention with their professional expertise properly. The aim of this review was to explore and analyze recent studies related to e-learning methods in improving psychiatric treatment for doctors and nurses in primary care facilities. The study design employed a narrative literature review based on related studies. Various databases were searched to obtain a critical appraisal on the resources used to develop e-learning programs in psychiatric treatment. Studies with empirical designs, peer-reviewed, written in English, and published between 2010 and 2019 were selected for this review. A total of seven research articles were selected for review. This review classified three main topics which were the creation of a comprehensive e-learning method, the benefits of elearning, and an evaluation of the e-learning method. E-learning innovation demonstrated to provide more effective benefits for both managers and beneficiaries, i.e. healthcare workers (doctors and nurses).
\end{abstract}

Keywords: e-learning, treatment, psychiatry, doctors, nurses

\section{INTRODUCTION}

The rapid advancement of technology today makes educational innovations for healthcare professionals also have to answer to the circumstance's challenges. The concept of e-learning is all of the utilization of internet technology to deliver various learning media, which aims to improve knowledge and skills/performance. E-learning is also referred to as web-based learning, online learning, distributed learning, computer-assisted instruction, and internet-based learning [1]. As a new paradigm in modern education, e-learning is an alternative learning model compared to the conventional face to face one. Learning using e-learning is supposed to be essential to develop the educational sector in Indonesia, mainly to expand equity and access to education. The implementation of e-learning in healthcare education institutions is pertinent to the future of nurses' education for continuous professional education (CPD) [2].

The primary advantages of e-learning are it can be accessed at any time and promptly available to anyone connected to the internet. With e-learning, geographic locations will not be a barrier and, theoretically, there will be no physical limit to the number of participants who attend courses or access the information [3]. This immediate access to learning materials via e-learning is important because learning is often an unplanned experience driven by clinical dilemmas in diagnosis or treatment. E-learning is the best method of learning due to the ease of instant access by participants and the learning content can be updated regularly. E-learning technology permits tutors to revise their learning content easily and quickly since e-learning content is easier to be updated than printed learning materials. Furthermore, feedback is a vital element in learning. In delivering the learning materials, it can be synchronized, where tutors and participants communicate in real-time (for example, internet chat forums and instant messages), or asynchronized, where participants can give feedback quicker and the feedback is given via email, online bulletin boards, newsgroups or other technologies [1].

Participants in e-learning can also personalize their learning according to their specific needs. Participants can control the content, sequence, speed, time, and media used in their learning. At the basic level, participants can select only modules from the courses relevant to them. With more sophisticated sites, participants can interact with tutors to create their own learning programs. Additionally, elearning standardizes course content and delivery, unlike, for instance, lectures in university which are given in separate sections of the same course. Moreover, automatic tracking and reporting of participants activities in e-learning reduce administrative works. Outcome assessments can also be entered to give evidence whether learning activities have been carried out. E-learning sites often incorporate automated documenting and assessments which provide evidence of learning for CPD logs [2]. These can be 
personalized with the user's learning objectives and based on reflections on the learning accomplishment. Innovative methods include the use of virtual patients, multimedia, and interactivity; for example, best practice manuals, alongside video interviews with experts in their fields (patients and professionals).

Mental disorders are defined as changes in behavior, feelings, and thoughts which are extraordinary and are not well realized and can pose a threat to the patient and others. As per Law Number 36 of 2009 concerning health, individuals with mental disorders who might threaten their and/or other people safety are required to receive medication and treatment at healthcare service facilities [4]. Early detection of mental disorders by medical personnel and nurses in primary care facilities is essential.

Meanwhile, psychiatric emergencies are any disorder in thinking, feeling or behavior that requires immediate therapeutic interventions or treatment. Psychiatric emergency issues can also be due to a result of general medical conditions showing psychiatric symptoms or as a result of adverse effects of medicines/substances or intoxication or reactions between a few types of medicines [4]. In psychiatric emergencies, the highest priority is treating agitated patients who can cause incidents to the patient and injure staff, causing psychological discomfort. Clinically, agitation can be observed as excessive and abnormal speech or physical attacks, specific motor behaviors, mounting anger, and psychomotor dysfunction in the patient. The assessment and treatment of patients with psychiatric emergencies are vital in providing emergency care [5],[6]. Along with the increasing services that must be provided to a patient experiencing an emergency, professionals are expected to have professional knowledge, competence, and skills in providing appropriate treatment. The limited resources in meeting learning requirements can be supported by utilizing the e-learning method. The training provided to the healthcare workers through elearning method can benefit professionals directly or mental patients indirectly. The aim of this review was to explore and analyze recent studies related to e-learning methods in improving preparedness in treating psychiatric emergencies patients for doctors and nurses in primary care facilities.

\section{METHOD}

In this literature review, narrative synthesis using textual approach method was employed to review and synthesize empirical data. This method focused on the summary, integration, and interpretation of related studies. The narrative approach method gave a systematic way to extract and synthesize previous studies' findings to obtain more specific data synthesis. Various databases were searched to obtain a critical appraisal on the resources used to develop e-learning programs in psychiatry treatment. Studies with empirical designs, written in English, and published from 2010 to 2019 were selected for the review in this study.

\section{RESULTS}

A total of seven articles were selected to be reviewed. The search on databases was carried out to identify related studies, using the keywords "e-learning", "psychiatric emergency", "training", and "mental health". The findings of the search in this review are presented in Table 1, showing that e-learning gives benefits effectively.

\section{DISCUSSION}

This results of this review classified three main topics: the creation of a comprehensive e-learning method, the benefits of e-learning, and the potential for developing e-learning methods.

\subsection{The Creation of a Comprehensive E- Learning Method}

To be able to create attractive and interesting e-learning programs in order to improve learning qualities, three conditions must be met in designing them:

a. Simple; the simple system will make it easier for participants to take advantage of the existing technology and menu. With the convenience on the panel provided, participants' learning time will be more efficient.

Personal; tutors can interact well with the participants, similar to communication taking place between teachers and students in the class. With a more personal approach and interaction, tutors are able to pay more attention to individual progress and assist in any problem faced by participants.

Table 1. Result

\begin{tabular}{|c|c|c|c|c|c|}
\hline Programs & Researchers (Year) & Sample & Design & Results & Recommendation \\
\hline $\begin{array}{l}\text { Sensory } \\
\text { approaches } \\
\text { using an e- } \\
\text { learning } \\
\text { package: a 3- } \\
\text { months } \\
\text { follow-up }\end{array}$ & $\begin{array}{l}\text { Meredith, Hutchens, } \\
\text { Kerley, Taylor and } \\
\text { Slaterry (2018) }\end{array}$ & $\begin{array}{l}\text { Mental health } \\
\text { personnel } \\
\text { (clinician) }\end{array}$ & $\begin{array}{l}\text { A multi-method } \\
\text { longitudinal } \\
\text { survey0 }\end{array}$ & $\begin{array}{l}\text { 1. There was a continuous increase } \\
\text { in clinicians' confidence and } \\
\text { knowledge after completing the } \\
\text { e-learning package and factors } \\
\text { affecting its implementation. } \\
\text { 2. Although there was a slight } \\
\text { decrease in scores after a three- } \\
\text { month follow-up, but the scores } \\
\text { were still higher than before } \\
\text { training. }\end{array}$ & $\begin{array}{l}\text { 1. The main challenges in } \\
\text { applying sensory } \\
\text { approaches were the } \\
\text { responsibilities of staffs and } \\
\text { time/resources. } \\
\text { 2. Educational support and } \\
\text { workplace changes were } \\
\text { also needed to increase the } \\
\text { inclusion of sensory }\end{array}$ \\
\hline
\end{tabular}




\begin{tabular}{|c|c|c|c|c|c|}
\hline Programs & Researchers (Year) & Sample & Design & Results & Recommendation \\
\hline & & & & $\begin{array}{l}\text { 3. Most of the respondents } \\
\text { reported that they implemented } \\
\text { sensory approaches after the } \\
\text { three months-training ended. }\end{array}$ & $\begin{array}{l}\text { approaches technique in the } \\
\text { clinical area. }\end{array}$ \\
\hline $\begin{array}{l}\text { An } \\
\text { interactive e- } \\
\text { learning } \\
\text { training } \\
\text { package }\end{array}$ & $\begin{array}{l}\text { Lamph, Sampson, } \\
\text { Smith, Williamson, } \\
\text { and Guyers (2017) }\end{array}$ & $\begin{array}{l}\text { Mental health } \\
\text { professionals }\end{array}$ & $\begin{array}{l}\text { Self-reported at } \\
\text { pre-, post- and } \\
\text { three-months } \\
\text { follow-up. }\end{array}$ & $\begin{array}{l}\text { 1. E-learning is an effective } \\
\text { learning method to increase } \\
\text { awareness of personality } \\
\text { disorders in respondents, with } \\
\text { results similar to face-to-face } \\
\text { training. } \\
\text { 2. E-learning can offer flexible } \\
\text { training as a compliment/reward } \\
\text { and can be an alternative to } \\
\text { face-to-face training. } \\
\text { 3. E-learning can also offer } \\
\text { refreshing alternative classes for } \\
\text { knowledge and understanding of } \\
\text { thinking frameworks or other } \\
\text { face-to-face methods. }\end{array}$ & $\begin{array}{l}\text { 1. Co-produced training can be } \\
\text { reflected in e-learning } \\
\text { programs, with careful } \\
\text { planning to ensure service } \\
\text { users are facilitated and } \\
\text { direct experiences are } \\
\text { aligned. } \\
\text { 2. Observational assessments } \\
\text { were led by the main } \\
\text { contributors and carried out } \\
\text { in geographic positions, } \\
\text { where these were } \\
\text { developed. } \\
\text { 3. This study was relatively } \\
\text { small and self-selected (not } \\
\text { randomized), so the findings } \\
\text { should be interpreted } \\
\text { cautiously. }\end{array}$ \\
\hline $\begin{array}{l}\text { Sensory } \\
\text { approaches to } \\
\text { e-learning } \\
\text { training } \\
\text { package }\end{array}$ & $\begin{array}{l}\text { Meredith, Yeates, } \\
\text { Greaves, Taylor, } \\
\text { Slattery, Charters, } \\
\text { and Hill (2017) }\end{array}$ & $\begin{array}{l}\text { Nurses and } \\
\text { occupational } \\
\text { therapists } \\
\text { working in } \\
\text { mental health } \\
\text { settings }\end{array}$ & $\begin{array}{l}\text { An online } \\
\text { survey using } \\
\text { pre- and post- } \\
\text { training }\end{array}$ & $\begin{array}{l}\text { 1. There was a significant increase } \\
\text { between pre- and post-training } \\
\text { in participants' knowledge } \\
\text { (subjective and objective), level } \\
\text { of confidence, and attitudes } \\
\text { towards using the sensory } \\
\text { modulation approach in mental } \\
\text { health settings. } \\
\text { 2. Custom-designed sensory } \\
\text { approaches in e-learning } \\
\text { packages which are effective, } \\
\text { accessible, acceptable, and can } \\
\text { be used to train healthcare } \\
\text { professionals in sensory } \\
\text { modulation approaches are } \\
\text { required. }\end{array}$ & $\begin{array}{l}\text { 1. Some of the problems that } \\
\text { hindered the application of } \\
\text { sensory approaches were } \\
\text { workplace culture and the } \\
\text { lack of access to effective } \\
\text { training of sensory } \\
\text { approaches. } \\
\text { 2. Since it was the first study } \\
\text { which analyzed the success } \\
\text { of sensory approaches using } \\
\text { e-learning package, the } \\
\text { results were considered as } \\
\text { preliminary and further } \\
\text { investigation was required. }\end{array}$ \\
\hline $\begin{array}{l}\text { Mobile } \\
\text { application: } \\
\text { PsychOut! }\end{array}$ & $\begin{array}{l}\text { Epp, Horne, Scolieri, } \\
\text { Kane, Bowser } \\
(2018)\end{array}$ & Trainee nurses & $\begin{array}{l}\text { Training } \\
\text { evaluation with } \\
\text { open-ended } \\
\text { responses, } \\
\text { observations, } \\
\text { and pre/post-test }\end{array}$ & $\begin{array}{l}\text { Based on the trainee nurses' } \\
\text { interactions with the application } \\
\text { and their perceptions of its } \\
\text { feasibility throughout the study, } \\
\text { the study indicated that this new } \\
\text { technology supported a viable } \\
\text { learning experience. }\end{array}$ & $\begin{array}{l}\text { The implication of this study's } \\
\text { results was to integrate mobile } \\
\text { applications with formal } \\
\text { learning settings. }\end{array}$ \\
\hline $\begin{array}{l}\text { Digital } \\
\text { Medical } \\
\text { Collections } \\
\text { to support } \\
\text { Radiology } \\
\text { Training on } \\
\text { the E- } \\
\text { learning } \\
\text { platform }\end{array}$ & $\begin{array}{l}\text { Buendia, Gayoso- } \\
\text { Cabada, and Sierra } \\
\text { (2018) }\end{array}$ & $\begin{array}{l}\text { Medical } \\
\text { residents }\end{array}$ & $\begin{array}{l}\text { An experimental } \\
\text { tool called Clavy }\end{array}$ & $\begin{array}{l}\text { 1. In this study, the Clavy platform } \\
\text { was utilized as the main } \\
\text { element. Clavy had proven to be } \\
\text { a useful tool for tutors in the } \\
\text { process of gathering, modifying, } \\
\text { and compiling instructional } \\
\text { guides in the radiology. } \\
\text { 2. The outcomes were very } \\
\text { positive, especially the } \\
\text { compliance level with the } \\
\text { radiology residents who } \\
\text { attended this course. }\end{array}$ & $\begin{array}{l}\text { 1. Most of the users } \\
\text { emphasized the need for } \\
\text { better image visualization, } \\
\text { and a closer correlation } \\
\text { between the descriptive case } \\
\text { and the questionnaire should } \\
\text { be developed. } \\
\text { 2. However, with most of the } \\
\text { course outcomes being } \\
\text { positive, it showed that the } \\
\text { potential of this educational } \\
\text { method was clear (to be } \\
\text { applied). }\end{array}$ \\
\hline $\begin{array}{l}\text { Mental } \\
\text { health first } \\
\text { aid training } \\
\text { using e- } \\
\text { learning }\end{array}$ & $\begin{array}{l}\text { Jorm, Kitchener, } \\
\text { Fischer and } \\
\text { Cvetkovski (2010) }\end{array}$ & $\begin{array}{l}\text { Australian } \\
\text { residents } \\
\text { (general) }\end{array}$ & $\begin{array}{l}\text { A randomized } \\
\text { controlled trial }\end{array}$ & $\begin{array}{l}\text { 1. E-learning and printed manuals } \\
\text { improved the knowledge aspect, } \\
\text { reduced stigma, and increased } \\
\text { self-confidence in participants } \\
\text { compared to the waiting list } \\
\text { group. } \\
\text { 2. E-learning also improved initial } \\
\text { response measures and was }\end{array}$ & $\begin{array}{l}\text { 1. Limitations in this study } \\
\text { were the varying levels of } \\
\text { education and mental health } \\
\text { literacy of the participants. } \\
\text { 2. Limiting the possibility of } \\
\text { improvement from training } \\
\text { 3. In addition, the } \\
\text { generalization of other }\end{array}$ \\
\hline
\end{tabular}




\begin{tabular}{|c|c|c|c|c|c|}
\hline Programs & Researchers (Year) & Sample & Design & Results & Recommendation \\
\hline & & & & $\begin{array}{l}\text { superior in reducing stigma and } \\
\text { disability due to mental } \\
\text { disorders compared to printed } \\
\text { manuals. }\end{array}$ & $\begin{array}{l}\text { studies from other groups in } \\
\text { this study was unknown. } \\
\text { 4. Bias in respondent } \\
\text { characteristics reflected how } \\
\text { e-learning preferences were } \\
\text { related to the selection in } \\
\text { the randomized trial. }\end{array}$ \\
\hline $\begin{array}{l}\text { E-learning } \\
\text { and blended } \\
\text { models for } \\
\text { the delivery } \\
\text { of mental } \\
\text { health first } \\
\text { aid training } \\
\text { in the } \\
\text { workplace }\end{array}$ & $\begin{array}{l}\text { Reavley, Morgan, } \\
\text { Fischer, Kitchener, } \\
\text { Bovopoulos, and } \\
\text { Jorm (2018) }\end{array}$ & $\begin{array}{l}\text { Civil servants } \\
\text { in Australia }\end{array}$ & $\begin{array}{l}\text { Randomized } \\
\text { controlled trial }\end{array}$ & $\begin{array}{l}\text { 1. E-learning Mental Health First } \\
\text { Aid (MHFA) and blended } \\
\text { MHFA courses had a positive } \\
\text { effect than PFA e-learning. } \\
\text { 2. More specifically on knowledge } \\
\text { of MHFA, desire for social } \\
\text { isolation, beliefs about } \\
\text { professional care, intentions and } \\
\text { confidence in helping someone } \\
\text { and personal stigma against } \\
\text { people with depression or post- } \\
\text { traumatic stress disorder (PTSD) }\end{array}$ & $\begin{array}{l}\text { 1. There was a minimal, } \\
\text { insignificant difference } \\
\text { between e-learning MHFA } \\
\text { and blended MHFA courses } \\
\text { on this outcome } \\
\text { measurement. } \\
\text { 2. However, users were more } \\
\text { likely to rate blended } \\
\text { MHFA courses in terms of } \\
\text { usability, number of courses } \\
\text { learned, and intention to } \\
\text { recommend courses to } \\
\text { others. }\end{array}$ \\
\hline
\end{tabular}

b. Fast; service is supported with speed, fast response to complaints, and tailored to the students' needs, so that learning improvements can be carried out as soon as possible by the tutors or managers.

It is needed to design a comprehensive e-learning training method, but simple, easy-to-operate and fast to achieve the expected competencies of a training [8].

\subsection{The Benefits of E-Learning}

E-learning is an effective delivery method to enhance awareness of personality disorders in respondents, with results similar to face-to-face training. E-learning can offer flexible training as a compliment/reward and be an alternative to face-to-face training [9]. Base on study by Meredith et.al, e-learning can offer a refreshing alternative class for knowledge and understanding of thinking frameworks or other face-to-face methods. The results exposed a continuous increase in clinicians' confidence and knowledge after completing the e-learning package and factors affecting its implementation. Most of the respondents reported that they implemented sensory approaches after the three months of training ended [10]. Furthermore, there was a significant increase in participants' knowledge (subjective and objective), level of confidence, and attitudes towards using the sensory modulation approach in mental health settings between pre- and posttraining. Therefore, it is necessary to custom-designed sensory approaches in e-learning packages which are effective, accessible, acceptable, and can be used to train health professionals in sensory modulation approaches [10].

Based on trainee nurses' interaction with the mobile application and their perceptions of its feasibility throughout the study, the study indicated that new technology supported a viable learning experience. In a study that used the Clavy platform as the main element, Clavy proved to be a useful tool for tutors in the process of gathering, changing, and compiling instructional guides in radiology. The participants' outcomes were very positive, especially on the compliance level with the radiology residents who attended this course. This e-learning improved the knowledge aspect, reduced stigma, and increased confidence in participants than the waiting list group [11]. E-learning also improved initial response measures and was superior in reducing stigma and disability due to mental disorders compared to printed manuals [12]. Meanwhile, MHFA e-learning had a positive effect, specifically on MHFA knowledge, desire for social isolation, beliefs about professional care, intentions and confidence in helping someone and personal stigma against people with depression or PTSD [13].

\subsection{The Potential for Developing E-Learning Methods}

Systematic e-learning development is a means to prepare for the future. This systematic development of e-learning make it possible to see the current condition before a leap (e-learning) is made and can avoid fatal mistakes when elearning has been implemented. Developing e-learning systematically also forces policymakers to think and manage the time, resources, and efforts needed [8][9]. Moreover, systematic e-learning development helps to identify priorities. It serves to guide the forces by shaping the regulations for institutional development and growth. It also identifies the positive and negative aspects of elearning development, regarding what should be continued, what should be changed, and what might be done. Furthermore, the development of systematic e-learning helps to maintain the quality of e-learning to be satisfactory and delivery self-management of the health professional[14][15].

\section{CONCLUSION}

Handling psychiatric cases in the community and at the healthcare center is vital for further treating people with mental health disorders. Hence, healthcare workers (doctors and nurses) are required to carry out this crucial intervention with their professional expertise properly. E-learning 
innovation gives more effective benefits for both managers and beneficiaries, i.e. healthcare workers (doctors and nurses). The training provided to the healthcare workers through e-learning method can benefit professionals directly or mental patients indirectly.

\section{AUTHORS' CONTRIBUTIONS}

The authors confirmed contributions to the paper as follows: study concept and design, data collection, analysis and interpretation of results, draft manuscript preparation: Shanti Wardaningsih, Warih Andan Puspitosari, and Asroni. All authors reviewed the results and approved the final version of the manuscript.

\section{ACKNOWLEDGMENTS}

Author would like to express gratitude to Universitas Muhammadiyah Yogyakarta for all of the support during the process of this literature review.

\section{REFERENCES}

[1] J. G. Ruiz, M. J. Mintzer, and R. M. Leipzig, The impact of e-learning in medical education, Academic Medicine $81 \quad$ (3) (2006) 207-212. DOI: https://doi.org/10.1097/00001888-200603000-00002

[2] F. Fandianta, G. Y. Sanjaya, W. Windyandana, Fleksibilitas Belajar Melalui Metode Blended learning, Jurnal Pendidikan Kedokteran Indonesia: The Indonesian Journal of Medical Education 2(2) (2013) 146-153. DOI: https://doi.org/10.22146/jpki.25178

[3] J. Cook, D. Holley, and D. Andrew, A stakeholder approach to implementing e-learning in a university, British Journal of Educational Technology 38(5) (2007) 784-794. DOI: https://doi.org/10.1111/j.14678535.2007.00755.x

[4] Law of Health of Republic of Indonesia (2009). no.36

[5] Regulation of Minister Health of The Republic of Indonesia (2018). no 47

[6] Minister of Health Decree Republic of Indonesia no 1627/Menkes/SK/XI/2010

[7] A. Pratiwi, A. W. Jadmiko, A. Widodo, Modification Of The Psychiatric Emergency Patient Acuity Tool Within A Triage System In An Emergency Unit, Advanced Science Letters 23 (12) (2017) 1255912562. DOI: https://doi.org/10.1166/asl.2017.10816

[8] P. Meredith, H. Yeates, A. Greaves, M. Taylor, M. Slattery, M. Charters, M. Hill, Preparing mental health professionals for new directions in mental health practice: Evaluating the sensory approaches e-learning training package, International journal of mental health nursing 27(1) (2018) 106-115. DOI: https://doi.org/10.1111/inm.12299

[9] G. Lamph, M. Sampson, D. Smith, G. Williamson, and M. Guyers, Can an interactive e-learning training package improve the understanding of personality disorder within mental health professionals?, The Journal of Mental Health Training, Education and Practice 13(2) (2018) 124-134. DOI: https://doi.org/10.1108/JMHTEP-03-2017-0023P.

[10] Meredith, S. Hutchens, L. Kerley, M. Taylor, and M. Slattery, Educating mental health staff in sensory approaches using an e-learning package: A 3-month follow-up, International Journal of Therapy And Rehabilitation, 25(8) (2018) 425-436. DOI: https://doi.org/10.12968/ijtr.2018.25.8.425

[11] F. Buendía, J.Gayoso-Cabada, J.-L. Sierra, Using digital medical collections to support radiology training in e-learning platforms, in: V. PammerSchindler et al. (Eds.), Proceedings of the Lifelong Technology Enhanced Learning (EC-TEL), Springer, Nature, Switzerland, 2018, pp. 566-569. DOI: https://doi.org/10.1007/978-3-319-98572-5_46

[12] A. F. Jorm, B. A. Kitchener, J. A. Fischer, S. Cvetkovski, Mental health first aid training by elearning: A randomized controlled trial, Australian and New Zealand Journal of Psychiatry 44(1) (2010) 1072-1081.

DOI: https://doi.org/10.3109/00048674.2010.516426

[13] N. J. Reavley, A. J. Morgan, J. A. Fischer, B. Kitchener, N. Bovopoulos, A. F. Jorm, Effectiveness of eLearning and blended modes of delivery of Mental Health First Aid training in the workplace: randomised controlled trial, BMC Psychiatry 18(1) (2018) 312. DOI: https://doi.org/10.1186/s12888018-1888-3

[14] C. D. Epp, J. Horne, B. B. Scolieri, I. Kane, A. S. Bowser, PsychOut! a Mobile App to Support Mental Status Assessment Training, in: V. Pammer-Schindler et al. (Eds.), Proceedings of the Lifelong Technology Enhanced Learning (EC-TEL), Springer, Nature, Switzerland, 2018, pp. 216-230. DOI: https://doi.org/10.1007/978-3-319-98572-5_17

[15] Lawn, S., Zhi, X. \& Morello, A. An integrative review of e-learning in the delivery of self-management support training for health professionals. BMC Med Educ 17, 183 (2017). https://doi.org/10.1186/s12909$\underline{017-1022-0}$ 